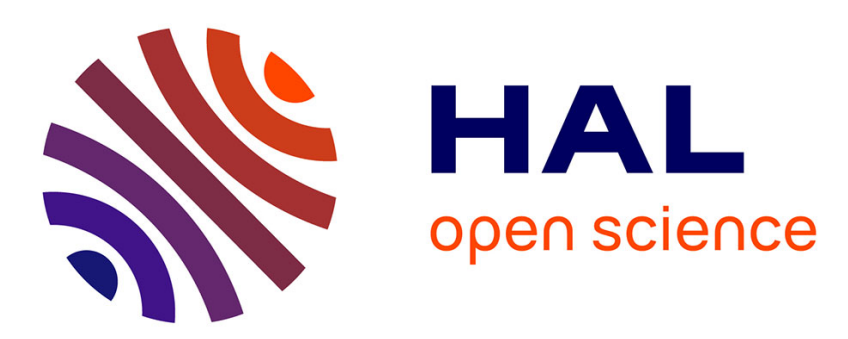

\title{
Bargaining on Law and Bureaucracies: A Constitutional Theory of Development
}

Eric Brousseau, Yves Schemeil, Jérôme Sgard

\section{To cite this version:}

Eric Brousseau, Yves Schemeil, Jérôme Sgard. Bargaining on Law and Bureaucracies: A Constitutional Theory of Development. Journal of Comparative Economics, 2010, 38 (3), pp.253-266. 10.1016/j.jce.2010.07.004 . hal-01052975

\section{HAL Id: hal-01052975 \\ https://hal-sciencespo.archives-ouvertes.fr/hal-01052975}

Submitted on 29 Jul 2014

HAL is a multi-disciplinary open access archive for the deposit and dissemination of scientific research documents, whether they are published or not. The documents may come from teaching and research institutions in France or abroad, or from public or private research centers.
L'archive ouverte pluridisciplinaire HAL, est destinée au dépôt et à la diffusion de documents scientifiques de niveau recherche, publiés ou non, émanant des établissements d'enseignement et de recherche français ou étrangers, des laboratoires publics ou privés. 


\section{AUTHOR QUERY FORM}

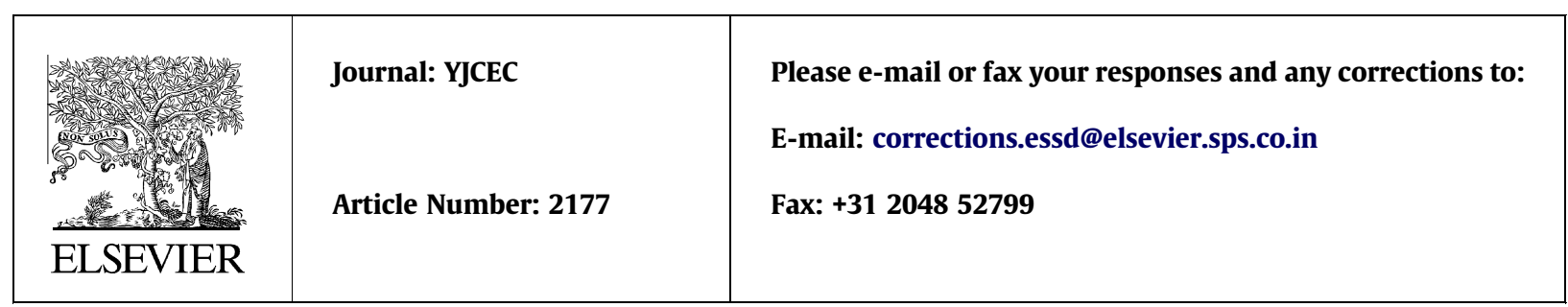

Dear Author,

Please check your proof carefully and mark all corrections at the appropriate place in the proof (e.g., by using on-screen annotation in the PDF file) or compile them in a separate list.

For correction or revision of any artwork, please consult http://www.elsevier.com/artworkinstructions.

Any queries or remarks that have arisen during the processing of your manuscript are listed below and highlighted by flags in the proof. Click on the ' $\mathrm{Q}$ ' link to go to the location in the proof.

\begin{tabular}{|c|c|}
\hline $\begin{array}{l}\text { Location in } \\
\text { article }\end{array}$ & $\begin{array}{l}\text { Query / Remark: click on the Q link to go } \\
\text { Please insert your reply or correction at the corresponding line in the proof }\end{array}$ \\
\hline$\underline{\mathrm{Q} 1}$ & Please provide complete postal address for affiliations ' $a-c$ '. \\
\hline$\underline{\mathrm{Q} 2}$ & $\begin{array}{l}\text { Please check whether the designated corresponding author and his e-mail are correct, and } \\
\text { amend if necessary. }\end{array}$ \\
\hline$\underline{\mathrm{Q} 3}$ & $\begin{array}{l}\text { Please provide 3-5 Research Highlights. For more information, see www.elsevier.com/ } \\
\text { research highlights. }\end{array}$ \\
\hline$\underline{\mathrm{Q}}$ & $\begin{array}{l}\text { As per journal requirements, KEYWORDS and JEL are mandatory. Please provide the } \\
\text { same. }\end{array}$ \\
\hline$\underline{\mathrm{Q} 5}$ & $\begin{array}{l}\text { References "McMillan and Woodruff }(1999,2000) \text { have been cited in the text but not in the } \\
\text { list. Please check. }\end{array}$ \\
\hline$\underline{\mathrm{Q} 6}$ & $\begin{array}{l}\text { As per journal instruction authors' given names in full, so please provide the same for all } \\
\text { references. }\end{array}$ \\
\hline Q7 & Please update reference "Benito (forthcoming). \\
\hline
\end{tabular}




\title{
Bargaining on law and bureaucracies: A constitutional theory of development ${ }^{\text {th }}$
}

\author{
4 Eric Brousseau ${ }^{\mathrm{a}, *}$, Yves Schemeil $^{\mathrm{b}}$, Jérôme Sgard $^{\mathrm{c}}$ \\ $5 \quad{ }^{a}$ EconomiX, Université de Paris $X$, France \\ $6 \mathbf{Q 1}{ }^{\mathrm{b}}$ University of Grenoble and IUF, France \\ $7 \quad{ }_{C}$ CERI/Sciences-Po and Université Paris Dauphine, France
}

\section{A R T I C L E I N F O}

Article history:

Available online $\mathrm{xxxx}$

\begin{abstract}
A B S T R A C T
Brousseau, Eric, Schemeil, Yves, and Sgard, Jérôme-Bargaining on law and bureaucracies: A constitutional theory of development

The process of development is linked to the rise of an integrated and competitive economy and polity that allow a maximal division of labor and innovation. This process relies on two intertwined dynamics. First, in the establishment of the rule of law, legal instruments are appropriated by those who call for more autonomy, resulting in a progressive equalization of rights. Second, development of a capable and impartial state is a prerequisite to implementation of rights, including their translation into services delivered to citizens. The mutual expansion of these dynamics relies on a vertical negotiation between the elite and the governed. The governed call for rights that are more firmly established and more extended. The ruling elite can grant these rights to maintain its legitimacy and hence its recognized authority. This model allows discussing the sustainability of various paths of $\mathbf{Q} 327$ institutional change in processes of development by identifying the potential virtuous 28 dynamics and hindering factors-and how the latter may be overcome. Journal of Compara- Q4 29 tive Economics xxx ( $\mathrm{xx}$ ) (2010) $\mathrm{xxx}-\mathrm{xxx}$. EconomiX, Université de Paris $\mathrm{X}$, France; 30 University of Grenoble and IUF, France; CERI/Sciences-Po and Université Paris Dauphine, 31 France.

(c) 2010 Published by Elsevier Inc. on behalf of Association for Comparative Economic Studies.

"Political economy, considered as a branch of the science of a statesman or legislator, proposes two distinct objects: first, to provide a plentiful revenue or subsistence for the people, or more properly to enable them to provide such a revenue or subsistence for themselves; and secondly, to supply the state or commonwealth with a revenue sufficient for the public services. It proposes to enrich both the people and the sovereign."

Adam Smith (1776). The Wealth of Nations, Book IV, introduction.

\footnotetext{
This paper draws from two earlier working papers, entitled "Will the World Be Ever Governed? The Dynamics of a Global Constitutionalization Process" and "Constitutions, State and Development", that were discussed in various working groups. This version (and previous ones) benefited from the comments of Lee Alston, Bruno Amable, Bertrand Crettez, Mike Dowdles, Robert Ellickson, Marc Flandreau, Peter Murrel, John Nye, and John Wallis. Avner Greif and Chris Kingston made precious suggestions. Anonymous referees also provided useful recommendations. We are indebted to these colleagues, though the usual caveat applies.

* Corresponding author.

E-mail address: eric@brousseau.info (E. Brousseau).
}

0147-5967/\$ - see front matter @ 2010 Published by Elsevier Inc. on behalf of Association for Comparative Economic Studies. doi:10.1016/j.jce.2010.07.004 


\section{Introduction}

It is usually assumed that the interaction between the economics and politics is dysfunctional in developing countries. Why does it seem such a stable situation? Since the early 1990s, both mainstream and other economists have addressed the issue with renewed calls for a more thorough approach to studying the role of states and institutions in market economies. Transition in Eastern Europe and the experience of high growth and crises in emerging economies played a key role in rekindling these debates. Still, the field is marred with serious research shortcomings, the most conspicuous of which is the difficulty of accounting for state action and for the role of the legal regime in promoting a dynamic economy. The role of the state as builder and maintainer of the economic infrastructure is widely acknowledged by most economists. At the same time, the transition from a state manipulated by a rent-seeking elite to an organization providing the framework for an efficient market economy remains a puzzle. As indicated by the debates around the notions of "legal origin" and "legal transplants", the mechanisms by which some legal principles would favor growth and the process by which they could be implemented are open questions.

This paper argues that development is conditioned by a parallel and interacting development of the rule of law, whose central features are the formalization and hierarchization of norms within a consistent framework, and public bureaucracy, which is characterized by independence and technical capability. Together they guarantee the credibility and evolutivity of the social pact as well as the implementation of an institutional framework favoring division of labor, collective action, and innovation. Pascal observed that "Justice without force is powerless; force without justice is tyrannical" (Pensée \#103). Likewise, we argue that legal formalization is key to economics and political integration: legal norms are necessary to grant legitimacy and to control the coercive capability of the state; and a skilled and neutral bureaucracy is required to provide access to public goods and ensure the transforming of de jure rights granted to citizens into de facto rights that can be opposed against others.

In order to analyze the process of state building and legal evolution, this paper builds on the notion of constitutionalization. Rather than viewing rights as being established once (under conditions that are often unique) or being the corollary outcome of an external dynamic, we envisage rights-both political and economic-as the product of an ongoing bargaining process. Rights are debated, fought over, supported, and possibly renegotiated by unequal (though purposeful) agents who interact with their rulers.

In particular, we consider the vertical delegation of authority by individuals to political rulers. This delegation aims to provide the ruler(s) with the capability to establish both the fundamental rights of individuals and the basic rules of social exchange in a given society. The problem with rulers is that, once endowed with considerable power, they may trample on the individual and property rights of their subjects. We contrast two types of constitutional delegations. Under a liberal regime, the governed are able to establish strong guarantees. The recognition of extended and equal fundamental rights to allcombined with a balance of power in the organization of the relationship among authorities-binds the rulers to the governed. In order to maintain their leadership position, rulers must please the governed by efficiently providing them with the public goods they need. Yet in the absence of strong guarantees, rulers are likely to bargain with different groups in society to guarantee them specific (and thus unequal) rights. The result is a sustainable coalition in which various individuals and groups obtain rents. In this context, which in our framework is defined as a despotic constitution, the governed are unable to credibly balance the power of those benefiting from a constitutional delegation. In response, the governed tend to grant delegations to several rulers in charge of different dimensions of collective coordination-typically local communities, professional guilds, or warlords. This way of challenging the power of rulers allows the population to limit capture, but it leads to inefficiencies in collective coordination and in the provision of public goods. First of all, authorities are not likely to operate at the prope scale. Second, competition among rulers can hinder their capacity to provide order and may even result in (possibly violent) conflict.

Starting from this, we show that there is an intrinsic dynamic of constitutionalization processes by which citizens-who may have been granted unequal fundamental rights at a particular historical moment-call for an extension and equalization of their rights, which in turn leads to the emergence of liberal orders characterized by strong equality of rights. This promotes competition, facilitates innovation, and boosts participation in collective action, thereby promoting economic and civic development. The main driver of this evolution is the "call" of the governed for adjustments to the existing constitutional arrangement so that they can reap the benefits of wealth and autonomy from their increased capacities. The essential inhibitor to such development is the desire of elites to preserve their rents and their share in a despotic regime (or natural state or oligarchic society, to cite other categories featured in this literature). However, the elite need political support and revenues from tax, for which they bargain by offering to devolve more rights to (some groups of) citizens.

On the basis of this model, we analyze the current situation in the developing world by questioning the sustainability of various paths of institutional change. Section 2 returns to the literature and historical evidence on the link between institutions and development, and it also discusses our influences and this contribution. Section 3 develops our analysis of the relationship between the institutional framework and the economy, highlighting a "growth and legitimacy" loop as characteristic of liberal regimes. Section 4 focuses on the dynamics of institutional evolutions, stressing the role of legal formalization and bureaucratic capabilities, and division of labor. We conclude in Section 5 by remarking on how both the law and the state are meant to be nonnegotiable mechanisms for easing negotiation among society's stakeholders and guaranteeing the resulting agreements. 


\section{Related literature and historical narratives}

By relying on too narrow a vision of English history-namely, the Glorious Revolution-several recent accounts of the relationship between institutions and development attempt to identify a "founding event". However, this viewpoint could bias an understanding of the process of institutional transformation, and it could also lead to a misplaced focus on what may only seem to be causal relationships. After all, 1688 was but one part of a longer history that explained the rise of a liberal constitution in the United Kingdom (see Section 2.1). Here we emphasize the key role played by the vertical bargaining between the rulers and the governed (Section 2.2), a process to which the cumulative establishment of political and economic rights is central (Section 2.3). Bargaining over the legal order is the core of the relationship by which both the rulers and the governed mutually recognize their prerogatives and duties. Negotiating about new or clearer rights on the basis of previous results is a never-ending process of reformulation and reestablishment of both individual rights and legitimacy to rule. The rise of modern societies relies on a formalization and hierarchization of legal norms that allow wide-scale integration and the actual emancipation and empowerment of individuals, after which individual wealth and capacities are no longer subject to unilateral capture by any ruler (Section 2.4). The key implementor and guarantor of the constitutional pact and the legal order is a public bureaucracy à la Weber. Because it is procedural, a public bureaucracy tends to guarantee the mutual commitment among citizens and between governed and rulers (Section 2.5). Although we focus on formalism, we do not ignore complementarities between informal and formal norms. In modern societies, formalization does not eliminate informal norms so much as transform them into second-rank adjustment variables in the social exchange (Section 2.6).

\subsection{Continuity and gradualism in constitutional evolutions}

The 1688 English Revolution has become the benchmark model for a modern, liberal, pro-market revolution. The classic article by North and Weingast (1989) was especially instrumental in furthering this perspective, though it draws from a long tradition-namely, "Whig history". Today, the main attraction of this event-which recounts a landmark transition in the "rules of the game"-derives from its emphasis on the ulterior evolutions transpiring in England, and its singularity in a comparative perspective. Because this revolution was played out within a limited time frame and on a relatively narrow political arena, it can be promoted as an easily identifiable founding event. The revolution was waged mostly between elite factions, and this pattern persists in the model of North et al. (2009).

However, there are two problems with this approach. First is an overemphasis on discontinuity in political and economic institutions. A common reading of 1688 assumes that parliamentary oversight of taxation and government spending initiated a broad transition to private property and the rule of law. In fact, a large body of historical literature demonstrates that underlying trends had been at work in England for decades, if not centuries. Not only was there open conflict between King and Parliament in the first decades of the 17th century, this conflict unfolded within a social milieu of strongly established private rights and civil courts that included the lower strata of society (Murrell, 2009). On this score, Muldrew (1998) and Brooks $(1986,2008)$ provide many examples that range from local to national jurisdictions and from contract or land law to openly constitutional topics. In the spirit of Pocock's (1987) classic book, Cromartie (2006) analyzes how, in the century and a half before the English Civil War, the law and the courts emerged as core regulatory and controlling institutions despite the monarchy's absolutist tendencies.

The second problem stems from the broader difficulty of accounting for open conflicts over rights beyond that involving a small fraction of the elite. In his study of the Glorious Revolution, Pincus (2009) documents the nontrivial amount of open violence that was then triggered. Thus, even in the English case, an interpretation of the liberal transition as "negotiated" may be wanting. The experience of almost all other countries underscores how difficult (and often violent) the successful transitions to equal rights have been. Of course, the French Revolution leaps to mind as the classical counterpoint to the English exception. Nonetheless, extension of the liberal franchise did not typically follow the English pattern in countries as diverse as the United States, Germany, Spain, Japan-not to mention the more recent experiences of Central Europe and Latin America. If equal rights were essentially about transactions between elite groups, then palace coups (and the occasional "tea party") would have been enough to secure them, and the myth of the Bastille would be considerably less powerful.

Here is where our model of constitutionalization may help. Citizens and economic agents are the most potent aspect of an interactive framework in which both the extent and enforcement of their rights are continuously renegotiated with the rulers. Even when rights are narrow and unequal, agents rely on them to contest. They sue, bargain, and protest, and thus agents may change the game within which they interact. Constitutionalization becomes a process because agents' benefits cannot be limited to those deriving from one-off sovereign commitments.

\subsection{The vertical bargain between governed and rulers}

Our focus on legal bargaining sets us against those who define an illiberal order by the complete absence of rights for the population (e.g., Olson, 1993). Such writers typically build on a purely oppressive interpretation of Hobbes's Leviathan: first, people accepted peaceful oppression as preferable to anarchy and endemic violence, but then they discovered that the sovereign could not be controlled. Once the birth of a state is set in such terms, it is hard to see why a well-established, powerful despot or oligarchy would be willing to sign off its privileges. This is a common theme in much of the contemporary 
literature in political economy, whose perspective differs little from that of Karl Marx-and the subsequent critical tradition-that casts the state as an instrument in the hands of dominant, abusive forces. ${ }^{1}$ When institutions reflect equilibria of strategies among political coalitions, evolution requires either erosion of political support or reversal of coalitions. Thus, institutional change is essentially brutal, which explains the attempt to identify founding events.

Instead, we follow the analyzes developed by North et al. (2009) and Greif $(2005,2006,2008)$ of the progressive joint evolution of political safeguards and the economy. The limitation on the rulers' ability to extort the governed, together with the sovereign's support for the proper and low-cost performance of transactions, are essential. However, exogenous political competition is not the main driver of the elites' agreeing to enfranchise citizens and hence becoming vulnerable to economic and political competition. It is the endogenous call for security and wealth by individuals that drives the bargain. Subjects or citizens do expect the ruler to guarantee their rights, even if they are minimal or unequal. From this point, agents continue to call for more rights and for an equalization of them. Theirs is not a moral claim; rather, it is the straightforward result of competing self-interested individuals who want the same rights as their neighbors and competitors. This is the logic of extension and equalization. Indeed, sovereigns, rulers, and states must always deal with the option of the governed to exit the scope of their authority by resisting, bypassing, or emigrating. In coalition or not, rulers must negotiate with the governed because repression is costly. Even for rulers with means of oppression at their disposal, mutual recognition of rights may be a more effective way to implement a stable order-although at the likely cost of a de facto reduction in the scope of their power. ${ }^{2}$

\subsection{The dynamic of legal bargaining}

In this context, legal systems are more than a mere formalization of oppressive relations and a pact for sharing. For example, medieval serfs-though they remained third-class members of society-gradually obtained stronger property rights to their land plots as well as the capacity to sell part of their production against cash and to organize communally. Therefore, in line with Posner, we insist on the central role of legal bargaining in the evolution of the society and the economy. ${ }^{3}$ Rights establish individual capacity and legitimacy to act-whence the centrality of their renegotiation if violence is not a viable option.

Legal bargaining takes place between the rulers and the governed, and it leads to the enactment of laws. It is also decentralized, resulting from millions of contract settlements and conflict resolutions that continuously redefine and make more precise the boundaries of individual rights. This explains why evolution is incremental and periodically blocked. The decentralized and step-by-step negotiations and precedents may create tensions that result in political reforms or even revolution.

Legal systems are multilateral commitments that articulate entangled components; hence they are not easily transformed (unlike agreements on shared principles between two coalitions). This fact accounts for the slow pace of institutional evolution as well as the cumulative nature of institution building.

\subsection{Centrality of the Weberian bureaucracy}

Rights per se are not sufficient to emancipate individuals or to guarantee their pact with the rulers; in other words, rights have to be implemented and operationalized by the public bureaucracy. North et al. (2009) rightly emphasize the importance of the state's transformation from an organization captured by the elite to one that is independent and impersonal. The rise of a procedural (public) bureaucracy à la Weber is the issue here.

Bureaucracies and the actions of bureaucrats are severely framed to guarantee impersonal application of formal rules (Weber, 1922/1978; Merton, 1940; Wilson, 1989). Key structural elements of bureaucracies-such as transparency in division of administrative duties, appointment according to objective technical qualifications, long-term careers with meritbased promotions (Evans and Rauch, 1999), incentives for conformity to norms of professionalism (Tirole, 1994), and so forth-combine to implement the constitutional pact. First, as mentioned by many scholars (e.g., North, 1981; Wilson, 1989; Barro, 1991; Nee, 2000), bureaucracies provide a set of public goods corresponding to the citizens' rights. Second, as observed by Weber (1918/1988) and Evans (1995), bureaucracies limit the discretionary power of rulers and of all manner of coalitions. Procedures provide public bureaus with an inherent pattern for ensuring compliance with the rules (Rajan and Zingales, 2003). Procedures inherently aim for consistency and completion, thereby contributing to the "solidification" and impersonality of rights as well as to the nonnegotiability of the rule of law.

\footnotetext{
${ }^{1}$ Most approaches view development as being driven by a credible commitment of the government to enforce contracts, protect property rights, and facilitate trade (North 1981; Olson 2000; Tabellini 2005; Gwartney et al., 2006) or to destroy the oligarchic barriers that restrict entry to either the economy or the polity (Acemoglu et al., 2007; North et al., 2009). This credible commitment results from an equilibrium of power among the various components of the society who weigh the rents they receive under alternative orders. Exogeneous factors (e.g., political competition) or endogeneous ones (e.g., the relative development of groups, such as merchants or entrepreneurs) may progressively erode the coalition supporting a given constitutional order; such erosion can lead to a window of opportunity for institutional changes.

2 Although we agree with North et al. (2009) that the birth of despotic regimes may be explained by horizontal coalitions, we believe that society results from a vertical mutual recognition of each others' specific roles and rights. In bargaining horizontally, individuals rely on the status they achieve via vertical bargains.

${ }^{3}$ Posner (1972), followed by La Porta et al. (1998) and La Porta et al. (2008), states that the decentralization of lawmaking in common-law systems explains why they are more efficient than code-based legal systems. Hadfield (2008) points out that these contrasts are misplaced. In our view, the process of legalization is cumulative in both cases: either through judicial or political confrontations-and on the basis of controversies based on precedents or doctrinal debates-economic and civic agents will continue to renegotiate the boundaries and the extension of their rights in any legal system.
} 


\subsection{Rationalization of the legal order}

Certainly, the extensions of the legal order and of the state's capacity have their own drawbacks, as pointed out in particular by the public choice approach. Legal formalization can result into normative inflation and legal opportunism, raising transaction costs and boosting uncertainty instead of providing clarification and empowering members of the society. The Weberian bureaucracy could well lead to inefficient social planning and bureaucratic capture-which are especially dangerous when the state has the advantage of extensive supervision and/or strong coercion.

This explains the centrality of establishing a hierarchy of legal norms. Considering some norms (e.g., freedom and equality) to be more fundamental than others (e.g., protection against economic risks) facilitates endogenous control of the development of legal norms. New claims must be compatible with the effectiveness and distribution of most fundamental rights. More generally, hierarchical norms make it possible to deal with the competing claims of equality (hence competition, integration, and centralization) versus autonomy (hence the possibility of fragmentation and self-regulation). The hierarchy of norms also frames the intervention of public bureaus, which should efficiently provide public goods according to the granted rights. Direct consequences of this hierarchy are (1) the vertical division of power among levels of government and (2) regulation of the delegation of service provision to private entities.

\subsection{Interactions between formal and informal norms}

We focus mainly on the rise of formal norms, but we also recognize the interplay between the formal and informal order. Social actors play a part in both orders, and it is the tension between the two that calls for resolution. Because formal norms are less ambiguous and are amendable to wider social enforceability (i.e., beyond community boundaries), they seem to answer the call for an extension and equalization of rights. Formalization results also from the legal order's complexification due to the consolidation of norms and their resulting hierarchization. At least, this is one way to interpret the literature on private and self-regulation (among others, Milgrom et al., 1990; Ostrom, 1990; Greif, 1993; Pirrong, 1995; Greif, 2005, 2006), which shows how these mechanisms emerge in developing countries to compensate for a weak or nonexistent public order (McMillan and Woodruff, 1999, 2000), while in developed countries, industry-specific self-regulation simply "completes" the legal order (Bernstein, 1992, 2001; Richman, 2004).

\section{The socio-economic dynamics of alternative delegation contracts}

To better understand the economics and politics of transition to a liberal order, we propose an analytical framework based on the idea that any order relies on a delegation contract between individuals and an entity that becomes an order provider (see Section 3.1). We show how contrasted abilities in implementing self-enforcing safeguards to protect the governed explain differences in the success of establishing a collective order (Section 3.2). "Extended" delegations provide the public regulator with the legitimacy to define the collective interest and to arbitrate between private interests (Section 3.3). However, public regulators are granted different levels of recognized legitimacy (and resulting authority), depending on the guarantees provided to the governed. ${ }^{4}$ Hence we compare different types of constitutions-in particular, despotic versus liberal ones (Section 3.4). We show that liberal constitutions generate a virtuous growth-and-legitimacy loop at the root of economic development and growth (Section 3.5).

\subsection{Delegation at the roots of order-providing entities}

We consider individuals who recognize their collective coordination needs and who therefore decide to delegate ${ }^{5}$ the rights to establish collective order to an individual, such as a sovereign, or to a group either spontaneously settled (e.g., a community) or formally established (e.g., an organization). ${ }^{6}$ What matters is that individuals grant this entity the rights to establish order. Order results from agreement on rules-that is, rights to take action and to access or use resources-and from enforcement to guarantee compliance. A cost-benefit analysis can be applied to alternative ways of producing order (Barzel, 1989; North, 1990; Williamson, 1996). By agreeing to limit their ex post freedom of action, individuals might lose opportunities to adopt first-best behavior in certain circumstances; they might also be required to contribute to the production of collective services. Finally, there is the risk of rents being captured by the order provider. Agents compare the costs and relational hazards

\footnotetext{
${ }^{4}$ It must be clear that delegating individuals are the principals; the rulers being their agents. However, in the common language individual-citizens are often qualified as agents, while the rulers might be named as principals. To avoid confusion, citizens will not be referred as principals in the following, and rulers will not be qualified as agents.

${ }^{5}$ Delegation can be explicit or implicit. In this paper we consider that delegation is in essence "an act", even if there is not always a formal and explicit act of delegation. We acknowledge the historical fact that individuals are born into established orders. Yet they may then decide whether or not to opt out, toadhere to other complementary or substitute orders, or to create new orders. Delegation is therefore about the de facto mutual recognition of rights and dैuties between a ruler and the governed. Its implementation leads to de facto renegotiation between the two parties because there may be varying degrees of compliance with the agreement between them.

${ }^{6}$ Orders can be formal or informal. A formal order is based on an identified principal to whom agents, either explicitly or implicitly, delegate authority. An informal order is based on the convergence of individual expectations regarding who (e.g., what leader or community) should rule and ensure compliance (Aoki, 2001; Dixit, 2004. In this paper we focus on formal orders.
} 
just described with the benefits of being ruled. Fundamental benefits of delegating authority are solving problems of collective action in the provision of public goods; this includes the resources (e.g., a common language and monetary system, fraud avoidance mechanisms, quality assessment solutions) that facilitate bilateral deals and trade. If agents had to provide the corresponding collective services themselves or by contracting, then either the services would be more costly or externalities would prevent their production at an efficient level.

The logic of this delegation of authority to a ruler is collective. Individuals waiving their discretion to a ruler do so jointly because this is one way to form a coalition. The ruler becomes a mutual guarantor among those who accept being subordinate to her. In addition, she becomes an aggregator of individual means of coercion; this allows her to threaten any individual including those who do not delegate authority to her. Indeed, she is able to aggregate resources (physical strength, money, and/or knowledge) so as to allow and rationalize collective action. Delegation thus leads to the recognition of rights that can be opposable among individuals, since the ruler can force the compliance of both insiders and outsiders. Of course, there may be limits to this capacity.

\section{2. "Targeted" versus "Extended" delegation}

The two ends of a continuum from targeted to extended delegation can be compared for purposes of discussing the tradeoffs faced by agents who must decide about the scope and strength of authority to grant an order provider. Targeted delegation consists of granting a limited and focused authority to a ruler, whereas extended delegation consists of agreeing to be ruled in many domains and to be constrained, perhaps severely. Individuals consider a trade-off between empowering the ruler and bearing the risk of the ruler's extorting their wealth and reducing their freedom of action. Hence agents are naturally interested in credible safeguards against such extortion.

Safeguards result from competition among rulers, which can be both synchronic by division of authority and diachronic by repeated contest for temporary appointment (especially by election, but also through other modes of performance assessment). We focus here on the division of authority that results in a limitation of the scope of authority granted to each ruler and that is made enforceable by the competition among rulers. Indeed, each ruler considers the adverse effects of abuses of authority and so refrains from abuse, since its governed maintain the capacity to challenge any ruler by switching to reliance on another. From this perspective, the contrast between targeted and extended delegation lies in the ability to divide authority de facto or rather by an intended and credible organizational design. Targeted delegations grant narrow domains of competence to a set of independent rulers. In contrast, an extended delegation seeks to organize checks and balances among those who benefit from the delegation in order to prevent collusion. Unorganized division of authority has a cost in that the various orders provided by divergent rulers may well be inconsistent, overlapping, and/or incomplete. In addition, effects of scale and scope might be underexploited (Brousseau and Raynaud, forthcoming). These factors can reduce the capability of collective and interindividual coordination. On the other hand, organized division of authority also has a cost because incentives and informational rents must be abandoned to the holders of authority-and to those who check them-in order to guarantee compliance and efforts. In this case, however, the ruler is more widely empowered, which results in a greater ability to guarantee order, and thus individual rights. ${ }^{7}$

The choice between a targeted and an extended delegation depends on the trade-off just described and on individuals' needs. Extended delegation is granted to guarantee rights that are viewed as essential ${ }^{8}$ and therefore expects those rights to be firmly established.

\subsection{Legitimacy of public rulers in building the collective interest}

To maintain the cohesion of agents concerning any joint delegation, the ruler must take into account the interests of all her stakeholders and guarantee each of them a "fair" return on his delegation. Otherwise, individual agents will leave the coalition or (if it is too costly to leave) break the order. The ruler is therefore required to provide collective services that ensure an acceptable cost-benefit ratio to each of the delegating agents.

In that perspective, there is a substantial difference between the "public" ruler who benefits from an extended delegation and the "private" ruler who benefits from a targeted one. Indeed, the latter need only consider the narrow purpose she

\footnotetext{
${ }^{7}$ From the viewpoint of governed, avoiding coalition among the divided rulers is obviously essential. In unorganized systems of division of power, they are on the one hand impossible to prevent. On the other hand, they tend to be unstable. Let us contrast two cases. If rulers are unequal in rights or strength, the inequality yield strong competition among them. There are always rulers challenging the "despot", or attempting to bypass her unequal coalition pact; thus opening margins of discretion for the citizens. If rulers are equal, forming a stable coalition among them is very unlikely since, as in cartels, there are incentives to shirk and only very narrow possibilities to implement a self-enforceable mutual commitment among rulers. In organized systems of power, the vertical and horizontal division of power, as well as the development of specific mechanisms of appointment aimed at insulating from each other the various holders of legitimacy to rule (and additionally to make them accountable toward the citizens) precisely aims at avoiding the forming of stable coalitions. As pointed out in Section 4, however, preventing the stability of coalition among rulers is not the all point because once rights are well constitutionalized-both because they are strongly established by the legal order and embodied in the social division of labor (and therefore in assets and in the human capital)-rulers can hardly tamper them; which is one of the central argument in this paper.

8 It is important to remember that the notion of fundamental rights is subjective, dynamic, and endogenous. Individuals have endless needs, and any public regulator is likely to increase the level of its provision of rights and associated services simply to reinforce the justification for an extended delegation of authority in its favor (more on this in the next section).
} 
serves. Individuals join to delegate because they share a common specific interest in being provided with a single good. The ruler can easily aggregate costs and benefits of the alternative way of providing the good. In contrast, extended delegation covers many domains and thus deals with preferences of individuals concerning very different goods and services, which are difficult to measure in terms of a common currency. Yet the public ruler will need to do more than reconcile conflicting interests $^{9}$; she will have to "build" the collective interest. Individual preferences are nonaggregative-because the loss of (subjective) utility by one individual is not compensated by another individual's gain in utility-and so the ruler must be a "benevolent dictator" (à la Arrow) by defining the collective interest when deciding on the nature and level of public goods provision. The legitimacy of the public regulator depends on her attention to social cohesion as well as on the quality of constitutional safeguards that determine her degree of accountability.

\subsection{Despotic versus liberal constitutionalization}

Extended delegations might differ in terms of the quality of organized safeguards, and these differences have consequences for the level and equality of fundamental rights guaranteed to a political order's various adherents. In what we call the despotic model, ${ }^{10}$ there is unequal distribution of rights among the citizens. Unequal rights are both the consequences and the cause of the poor constitutional safeguards, because vertical inequalities in rights undermine the credibility of any contract between the rulers and the governed. Indeed, the most endowed agents can easily renegotiate any commitment. A liberal constitution, on the other hand, is characterized by equality of rights among all citizens, including rulers. We first show that a despotic constitution yields a political order resulting in social fragmentation that prevents both the extension of markets and an efficient provision of public goods (see Section 3.4.1). In contrast, equality of rights under a liberal constitution results in a "deepening" of the delegation of authority together with an extension of the constitutional contract's scope that favors economic integration and public efficiency (Section 3.4.2). The reduction of inequalities in rights characterizing the dynamic of liberal constitutionalization implies a hierarchization of norms and an extension of legal ordering, which are crucial to governance and to providing public goods at the appropriate level and through the correct channels, public or private (Section 3.4.3).

\subsubsection{The weak politico-economic dynamics of despotic constitutions}

All political orders evolve from preexisting ones. Agents that negotiate the delegation of authority are ex ante heterogeneous in terms of endowments, preferences, and localization within the networks that structure societies. In such settings, order-providing entrepreneurs-whether warlords, merchants, innovators, or rebels-look to resolve problems of coordination with solutions that can be adopted by groups; while the solutions are primarily designed to meet the interests and preferences of those entrepreneurs (see Brousseau and Raynaud, forthcoming). ${ }^{11}$ Collective orders are then made up of various "circles" that offer uneven benefits to individuals.

In the case of public orders, this results in inequality of actual rights between those favored by the rulers and other members of the society. Even though they may constitute the vast majority of the population, these "outsiders" may be exposed to various forms of discrimination with respect to taxation, market access, public infrastructure, protection of property rights, physical security, and so forth. A good example is the informal sector at the margins of large conurbations in present-day developing countries.

Under a liberal constitution, inequalities in rights between the rulers and the governed tend to be minimized, whereas such inequalities are huge under a despotic constitution. In a despotic regime, the governed are unable to secure credible safeguards from the public ruler. Hence they limit as much as possible the scope of delegation by recognizing the ruler's authority in only a few domains. Because this limits the sovereign's ability to provide public goods, subjects rely on local solidarities (e.g., family, lineage, ethnicity, guilds, municipal communities, gangs) to ensure the provision of most of them-though with little advantage in terms of size, scope, or specialization. Despite these inefficiencies, the constitutional arrangement may be quite stable. Individuals stand by their communal solidarities, which protect them against the despotic ruler; in turn, the constitutional pact is prevented from extending beyond its initial, minimal contract.

\subsubsection{The "legitimacy loop" of liberal constitutionalization}

Equality in rights under a liberal constitution favors the extension of individual rights for two cumulative reasons. First, rights result in the provision of public goods. Since these benefit all citizens, the formation of a majority coalition supporting

\footnotetext{
9 This is even more complex because the need for an extended delegation is a function of the potential conflict of claims among the members of a population. Indeed, the more conflicting claims over resources or mutual rights and duties, the more a mutual guarantor is required.

10 The notion of a "despotic regime" is somewhat dated and possibly Eurocentric. Starting with Montesquieu, despots have often been implicitly or explicitly oriental, non-Christian, and arbitrary-an intellectual legacy still present in the Weberian notion of a "sultanic regime". Others might prefer to contrast "liberal" with some other antonym, but we prefer "despotic" because it clearly includes both economic and political dimensions and, we assume, it can fairly be applied to both antique and contemporary experiences, Western and non-Western alike.

11 Brousseau and Raynaud (forthcoming) assume that agents are ex ante heterogeneous in the sense just described. Therefore, when common orders are being designed and adopted, norm setters or institutional entrepreneurs compete to coordinate agents or support collective action: they promote alternative solutions for a given coordination problem in a given community (e.g., by supporting market exchange or the production of public goods). Hence, the resulting order primarily reflects the preferences and needs of the winning party. Although every agent can expect to benefit from reduced transaction costs, the needs of core members of the groups designing and implementing the collective governance solutions will be better addressed than those of "fringe" agents. Indeed the latter will incur coordination costs that are higher than their first-best.
} 
the extension of these rights (and attendant benefits) is understandable. ${ }^{12}$ Second, to accommodate the plurality of interests that have equal legitimacy in a liberal regime, it is essential to formalize and manage mechanisms permitting all interests to be voiced. ${ }^{13}$ As a result, collective decision principles tend to rely on the majority preference. The socio-economic and the civic logics combine to establish an open-ended dynamic: as the demands for public good from a larger share of the population are better addressed and as the benefits of scale, scope, and specialization are better exploited on the supply side, the rulers benefit from increasing legitimacy and fiscal resources. This "legitimacy loop" enables the governing elite to derive private benefits from the high-powered delegations granted by the other tiers of society.

In a despotic regime, the contract between rulers and principals is narrower and much less dynamic. Since a large part of the population does not benefit from significant rights and since the voicing of objections is limited, it follows that the common interest is reduced: typically it amounts to security for all and a reduced package of services for the happy few. Given the reduced supply of public goods and services, no "legitimacy loop" can develop; moreover, the pool of resources from which rulers can draw rents remains much smaller than in a liberal regime.

\subsubsection{Integration and organization of the legal order}

We have shown that despotic and liberal orders have contrasting dynamics. In a liberal order, equality of rights within the polity, the benefits of centralization, and the underlying growth dynamic in the provision of public goods are powerful forces against the establishment of locally contracted orders. Equality among citizens tends to collide with limited access to locally provide public goods. Also, efforts to manage solidarity on an interindividual and voluntary basis might be viewed as attempts to escape broader solidarity, to weaken equality among citizens, or possibly to capture rents. Coalitions and communities are not, however, to be levelled, as a Jacobin, illiberal view would suggest. They are rather subsumed within a broader legal order, which becomes the ultimate arbiter of equality and autonomy, open competition and decentralization.

Here is the rationale beyond the construction of an integrated, hierarchic legal order. Because fundamental rights are established at the highest level of political order, so as to guarantee equality, they then have to confirm more decentralized orders, or norm-producers; conflicts of jurisdiction have to be adjudicated from above; private associations and coalitions are subjected to oversight, in case they would violate open access. The extension of legal ordering follows. Interactions between more autonomous agents and between public bodies are increasingly governed by formal, rule-based principles-contracts and private law in the former case, administrative and constitutional law in the latter.

Thus the development of equal, impersonal rights and of a consistent hierarchy of norms and jurisdictions is the backbone of economic and political integration under a liberal constitution. The outcome is a more efficient production of both private and public goods. On the other hand because a despotic order is founded on unequal rights, often attached to personal allegiance or communitarian solidarity, they typically add up in a fragmented overall normative order. With the nobility, free burghers, oppressed peasants, religious or ethnic minorities, all endowed with specific rights, both political mobilization and economic integration are difficult.

\subsection{The politico-economic dynamics of despotic versus liberal constitutions}

Our model describes a continuum of logic and features among private, despotic, and liberal delegations, which explains their contrasting dynamic properties. The continuum is summarized in Table 1.

Despotic and liberal constitutions present great contrasts in the potential for economic activity and growth. Under a despotic constitution, inherited inequalities and a fragmented legal order entail strong resistance to the extension of competitive forces. In contrast, a liberal constitution offers more scope for growth, market exchange, and social differentiation because equal individual rights drive the opening of markets to competition and challenge the existing distribution of wealth.

Under a liberal constitution, enfranchisement also allows the establishment of organizations that support collective action. In combination with entrepreneurial freedom, the rise of organizations (which inherently favor the accumulation and development of knowledge) stimulates innovation. Thus, there are two main drivers of the progressive extension of impersonal and equal rights to all citizens: (1) the increasing division of labor (thanks to markets and organizations) and the fostering of innovation (thanks to generalized competition and the capacity of organizations to accumulate collective knowledge) boost the surplus to be shared and (2) the provision of an enlarged set of public goods and of automatic and systematic insurance or solidarity mêchanisms enables substantial individual freedom with limited individual risks.

The resulting dynamics, which is at the core of the long-term experience of development, revolves around a powerful "growth and legitimacy" loop. On the one hand, open markets and lower transaction costs support integration and growth; on the other hand, effective constitutional guarantees and open access to political decisions extends bargaining across society and thus contributes to legitimacy. Dynamically, economic activity and civic participation may then feed back into the constitutional game: as underlying conditions and needs evolve, market infrastructure and nonmarket common goods may

\footnotetext{
12 The only limit to the extension of fundamental rights is the cost of the resulting services, which might exceed the willingness of influential coalitions to contribute to the common good. Resources conceded to the state may reach an equilibrium that reflects the relative concern in each society for market incentives versus collective solidarity (under conditions of declining marginal returns of public good provision).

13 Negotiation costs and delays preclude unanimity, so collective choices must be based on a mechanism that combines majority rule with freedom of expression.
} 
Table 1

Continuum of delegation types.

\begin{tabular}{|c|c|c|c|}
\hline & \multicolumn{3}{|l|}{ Type of delegation } \\
\hline & \multirow[t]{2}{*}{ Private } & \multicolumn{2}{|l|}{ Constitutional } \\
\hline & & Despotic & Liberal \\
\hline Scope of the delegation & Narrow & Limited set of fundamental rights & Extended set of rights \\
\hline Nature of the established rights & $\begin{array}{l}\text { To be permanently renegotiated } \\
\text { with the other stakeholders and } \\
\text { the enforcers }\end{array}$ & Individualized and based on personal ties & $\begin{array}{l}\text { Anonymous and opposable } \\
\text { to everyone }\end{array}$ \\
\hline Collective good provision & Club goods & Club goods and basic public goods & $\begin{array}{l}\text { Extended set of public } \\
\text { goods }\end{array}$ \\
\hline $\begin{array}{l}\text { Guarantees between rulers and } \\
\text { governed }\end{array}$ & $\begin{array}{l}\text { Easy exit and splitting of } \\
\text { delegation among various } \\
\text { private regulators }\end{array}$ & $\begin{array}{l}\text { Bounded delegation to the sovereign combined } \\
\text { with parallel delegation to local rulers or } \\
\text { communities }\end{array}$ & $\begin{array}{l}\text { Checks and balances and } \\
\text { Bill of Rights }\end{array}$ \\
\hline Organizational support & Low-powered organization & $\begin{array}{l}\text { State specializes in violence and in the } \\
\text { manipulation of rents for the benefit of rulers }\end{array}$ & $\begin{array}{l}\text { Neutral and skilled } \\
\text { bureaucracy }\end{array}$ \\
\hline $\begin{array}{l}\text { Organization of the system of } \\
\text { norms }\end{array}$ & $\begin{array}{l}\text { Heterogeneous (and possibly } \\
\text { incompatible) orders }\end{array}$ & $\begin{array}{l}\text { Legal pluralism (characterized by } \\
\text { inconsistencies at the fringe of each domain) }\end{array}$ & Hierarchy of norms \\
\hline
\end{tabular}

Table 2

Politico-economic dynamics of constitutional regimes.

\begin{tabular}{|c|c|c|}
\hline & \multicolumn{2}{|l|}{ Constitution } \\
\hline & Despotic & Liberal \\
\hline Economic competition & Closed & Open (any position is challengeable) \\
\hline Political competition & $\begin{array}{l}\text { Winners take all (violence is tolerated) and no right to } \\
\text { compete for minorities/fringe members }\end{array}$ & $\begin{array}{l}\text { Checks and balances; peaceful and reversible } \\
\text { transmission of power }\end{array}$ \\
\hline $\begin{array}{l}\text { Capacity to create } \\
\text { organizations }\end{array}$ & $\begin{array}{l}\text { Restricted to the elite; personal rights are granted by the } \\
\text { sovereign }\end{array}$ & Open to all \\
\hline $\begin{array}{l}\text { Determinants of bargaining } \\
\text { position }\end{array}$ & Inherited personal and social status & $\begin{array}{l}\text { Equality in rights and meritocracy (biased by advantages } \\
\text { due to access to social and economic capital and partly } \\
\text { compensated by the state's provision of services) }\end{array}$ \\
\hline $\begin{array}{l}\text { Drivers of constitutional } \\
\text { change }\end{array}$ & Interpersonal bargaining in a multitier society & Collective bargaining to extend individual rights \\
\hline Legal regime & $\begin{array}{l}\text { Reduced to the recognition of alternative and } \\
\text { autonomous regimes of regulation }\end{array}$ & $\begin{array}{l}\text { Hierarchy of norms: constitution > public law > self- } \\
\text { regulation }\end{array}$ \\
\hline Role of the public bureaucracy & $\begin{array}{l}\text { To organize the system of rent genesis and distribution } \\
\text { and to secure the benefits of all stakeholders (including } \\
\text { the sovereign) }\end{array}$ & $\begin{array}{l}\text { To guarantee the openness and fairness of political and } \\
\text { economic competition and to organize the provision of } \\
\text { public goods to ensure legitimacy of the social contract }\end{array}$ \\
\hline Public good provision & $\begin{array}{l}\text { Centralized provision of security; community or local } \\
\text { provision of most public goods }\end{array}$ & $\begin{array}{l}\text { Mix of centralized and decentralized public provision; } \\
\text { mix of public and private provision }\end{array}$ \\
\hline Society and economy & Fragmented (and possibility of violence among groups) & Integrated economy and polity \\
\hline
\end{tabular}

be better governed. Collective learning also facilitates improvements in social technologies toward the end of better managing collective action or better dealing with specific individual or community needs. Table 2 summarizes our analysis of the politico-economic properties of alternative constitutional regimes.

\section{Bargaining and its collective consequences: formalization and hierarchization}

Behind the contrasted properties of alternative constitutional pacts, there is a common logic of evolution that we emphasize in what follows. Inequalities in rights always lead to a process of legal bargaining by which the less endowed call for an extension of their rights. They individually seek more capability and autonomy, which collectively results in a deepening of the division of labor and hence increasing wealth (see Section 4.1). Two interacting processes of institution building sustain the process of bargaining between rulers and governed and also explain the path dependency and relative irreversibility of the constitutional pact: the extension of the rule of law (Section 4.2); and the rationalization of the state and its establishment as a neutral or benevolent actor (Section 4.3). Both processes are instrumental to the growth-and-legitimacy loop characteristic of the process of liberal constitutionâlization (Section 4.4).

\subsection{Driving and hindering factors for constitutionalization: rulers versus the governed}

Our contractual approach to social order does not rely on a social contract perspective whereby ex ante free and skilled individuals negotiate a constitutional pact according to the distribution of bargaining power and the nature of their prefer- 
ences. Instead, we consider historical processes of constitutionalization by which members of the society, ex ante embedded in family and community structures, are progressively enfranchised by a ruler's recognition of individual rights.

In any actual order, some individuals are restricted in their capacity to access resources or in their right to live their lives as they would wish. Hence these agents have incentive to shirk vis-à-vis the existing set of rules or to call for the evolution of those rules, which results in bargaining. Bargaining can be implicit in the sense that a ruler may choose not to punish individuals who fail to comply with established rules. The ruler weighs the costs and benefits of enforcing the existing order against those associated with the amendments called for by dissident individuals and groups. Explicit or implicit bargaining results in a de facto mutual recognition of rights and authority.

When calling for an extension and strengthening of their individual rights, the governed are driven by two types of motivation: economic and civic. Economic agents call for security of property rights; freedom to contract (and to create organizations); and, more generally, open access to potential counterparts in the exchange although some individuals would prefer that their markets be isolated from competition). Civic motivations are based on recognizing that allegiance to a ruler generates not only collective solidarities but also dependencies that should be addressed. Rights to oversight and to reconsider or object to delegation prevent expropriation and make it possible to influence the production of public goods.

The call for more rights is not just a question of enfranchisement; it is also a question of empowerment and possibly of ethics. Rights are indeed understood as leading to the collective provision of services that either compensate for the destruction of traditional structures (e.g., a social "safety net" in place of families or clan solidarities) or allow one to benefit from-or at least to manage-the consequences of more freedom (typically via education). Empowering rights are the enabling condition for, and thus the counterpart of, increased complexity in social exchanges and increased interdependencies among individuals due to the deepening division of labor. Citizens might also call for an equalization of these extended sets of rights-motivated either by altruism or by a selfish ethic justified by the "veil of ignorance".

Facing the governed, the rulers have a vested interest in defending their prerogatives. While the governed can be expected to resist, they will compromise for two reasons. First, the resulting economic dynamic might well lead to an increase in their individual wealth (while the rulers' share decreases, and the contestability of their position increases). Second, rulers require the continuation of their legitimacy in order to govern and regulate. If they cannot establish terror (or if recourse to violence is counterproductive) then rulers must make concessions, especially if the governed have exit options or are able to unite.

There are, as well, two factors that hinder the dynamics of equalization and the extension of rights. The first factor is redistribution effects. All kinds of individual rents are suppressed with the equalization of rights and the rise of competition. Although increasing the surplus theoretically allows winners to compensate losers, the latter might still fear net losses. And even though the consequences of uncertainty have become increasingly socialized, uncertainty persists because competition makes any position challengeable and because innovation by its very nature questions established interests. As a result, there is redistribution between risk-seeking and risk-averse agents. Attitude toward risk depends partly on one's level of wealth, but it is also a basic psychological characteristic and a matter of individual preferences. Thus, despite the development of impersonal collective solidarity mechanisms, risk-averse agents may object to the extension of individual rights. The second hindering factor is the existence of switching costs. With the rise of generalized competition in the economy and in politics, individuals must learn to play new games, to put forth continuous effort (given the general contestability of all positions), and to update their skills. For this reason, coalitions formed by rent holders and agents fearing increased instability can be expected to defend the status quo.

\subsection{The rule of law: formalizing and hierarchizing norms}

The development of a liberal order depends on establishment of the rule of law. This rule of law features two intertwined dimensions: the formalization of all social interactions, to facilitate wide-scale interactions among individuals; and the hierarchization of norms (both within public norms and between public and private norms), to allow integration.

Formalization is indeed necessary for establishing a social pact on a wide scale. Rights become impersonal and generic because they are no longer based on privileges granted by ruler on a personal basis. Rights must be recognized by all, and agents comply because they recognize them voluntarily or are forced to do so. Rights also become negotiable and thus form the roots of any further interindividual or collective arrangements. Indeed, the sophistication of rights enables development of complex social "technologies"; these include political parties, complex systems of mutual duties, the sharing of direct or indirect financial stakes, and the combination of various risks and time horizons. This accounts for the necessity of making rights clear and of agreeing to collectively recognized systems that track their distribution and evolution (Arrunada, forthcoming).

We have remarked that the rule of law develops in two contrasting yet interconnected domains. First, the constitutional delegation between rulers and the governed must be made explicit. Under a despotic constitution, the notion of public interest is unclear, as are the duties of the sovereign toward her subjects. On the other hand, a liberal order requires not only the enactment of a formal constitution and Bill of Rights but also the emergence of a legal and jurisdictional hierarchy, headed by a supreme court, that is responsible for defending the rights of citizens vis-à-vis the ruler and also for nondiscrimination among citizens-in short, a judiciary oversighting of any infranational level of regulation and the settlement of jurisdictional conflicts. Beyond this organization of federalism and the public-private hierarchy, the second domain of a developing rule of law is in the implementation of a division of power à la Montesquieu-especially to manage the enactment of new rights and 
rules. The respective responsibilities of the three branches of government must be established so that accountability is assured.

The evolution of individual rights, however, does not derive solely from vertical negotiations between rulers and the governed; it also draws from horizontal negotiations within society. Examples include negotiations between employers and employees, landowners and tenants, creditors and borrowers, insurers and the insured, and service providers and clients. The myriad day-to-day negotiations and deals generate a need for harmonization-balanced, of course, by the "specificities" of transactions-in order to reduce transaction costs. Horizontal negotiations are notable for two reasons: (1) they are the process by which actual rights are clarified among the parties and (2) agents play a huge number of games to reshape the boundaries of their rights and/or to design local collective orders, either of which might well infringe on the rights of third parties. It is critical that these games ultimately be arbitrated by institutions that value equally the freedom to associate (and contract) and the need for clarity (and thus greater safety and lower transaction costs), open access, and solidarity. How these demands are addressed and balanced is what distinguishes various liberal experiences and their respective legal traditions.

The rise of the rule of law is driven by the need to reduce the "negotiability" of rights and by the will to change the balance of (bargaining) power. Citizens and private organizations prefer extended guarantees of their rights and agreements to threats of interindividual retaliation and community discipline. At least in liberal societies, the judicial and executive arms of the state offer these guarantees. Changing the balance of power is key to the enfranchisement of citizens and to guarantee open access to competition. Yet those who dominate markets or political orders have a vested interest in capturing rents and fending off competition-whence the continual need to complement and adjust regulations that support open access.

One of the enabling conditions for initiating this virtuous loop of the extension of legal ordering is a change in social conventions. Citizens must be convinced that legal bargaining is the game to play if they wish to pursue their goals in society. This requires that rights be credible. This is why the emergence of a state machinery aimed at enforcing and materializing legal rights is a necessary condition for the rise of a liberal order.

\subsection{The state's capacity as guarantor of the constitutional pact}

The growth-and-legitimacy loop cannot be started unless the state is credible as guarantor of the social pact. Such credibility is hard to come by because, in most despotic regimes, the state is seen by large fractions of the society as a means for the dominant (ruling and economic) class to oppress or capture the underclass. The challenge then is to transform the state as the credible guarantor of individual interests, and as the empowerer of individuals to exercise their rights. In the European historical experience, modern state bureaucracies emerged from the king's household in the face of pressing needs to organize, govern, and monitor the provision of public goods along impersonal, self-contained principles of instrumental rationality. The bureaucracy plays a dual role: it provides the empowering capabilities of the various components of the divided power, and it ensures the ground-level provision of public goods to the citizens.

This division of power succeeds if those in charge of making decisions, whether they are elected or appointed, can rely on an efficient and skilled bureaucracy providing them with the means to document cases, to study the various issues, to implement decisions, and then to analyze the effects of those decisions-to amend them as needed and also to accumulate knowledge. There are two essential conditions for such a bureaucracy. First, the various components of the state machinery should have their financial resources guaranteed so that they can independently manage their workforce and resist political pressure. Second, a general principle of meritocracy should manage the careers of civil servants, regardless of whether they benefit from lifetime guarantees or are employed for a limited period. This, in turn, requires formalizing and publicizing the appointment processes as well as the management of careers and remuneration.

In most developed nations, the state bureaucracy serves not only as the tool empowering decision makers but also as a third party between citizens and the ruling elite that prevents the latter from acting against constitutional and legal principles. This role is possible because the bureaucracy's own system of checks and balance does not allow those who make decisions to bypass the procedures and constraints of consistently applied legal principles-in particular, consistency with respect to constitutional principles. These constraints are both formal and informal: civil servants develop an ethos (of self-regulation) that is backed by formal sanctions.

After (effective) division of power, the second dimension of state action is provision of public goods to citizens. In this there are generally two goals, the first of which is to trigger a virtuous loop between the ability to provide public services and the capacity to raise taxes that will fund their production. The second goal is to favor an efficient organization of the production and delivery of these services, which affects the bureaucracy's internal organization as well as the optimal devolution of competences.

In this perspective, the hierarchization of norms under a liberal constitution allows for flexibility in the provision of public goods. Indeed, although public norms established at the highest level of constitutionalization may guarantee the provision of public goods to citizens, the way in which these goods are actually produced may be adapted to the specificity of their production function. It is therefore possible to decentralize by assigning the task of provision to local governments or to forprofit and non-for-profit private entities.

However, efficiency incentives and sanctions bear less on the state machinery than on a private firm in a competitive market. In the first place, because the state enforces equal rights and implements the common interest, its optimization function is qualitatively different from that of any single-issue organization (whether a private firm, nongovernmental organization, 


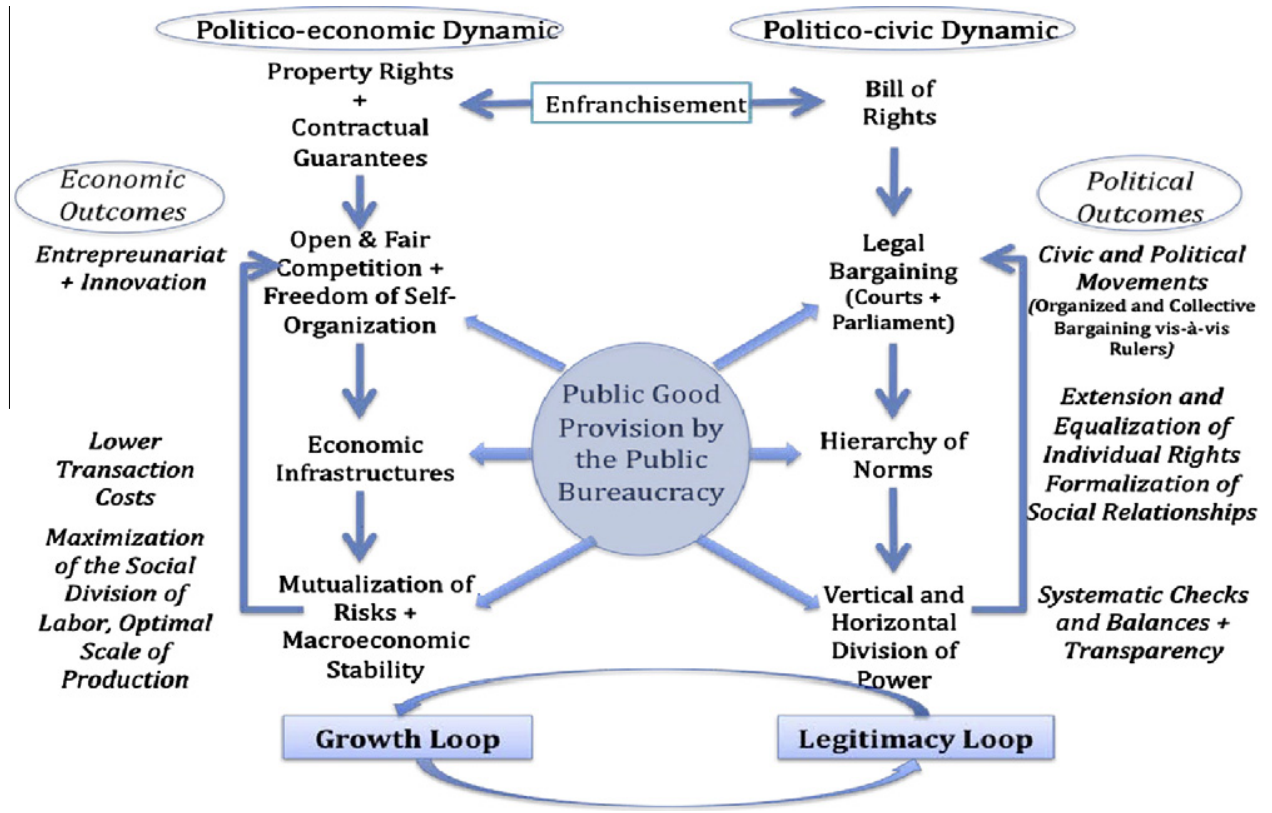

Fig. 1. Process of constitutionalization, state building, and development.

or club). Second, the state provides goods and services whose characteristics make it difficult to organize competition among producers. Third, solvency norms and contractual commitments cannot exercise hard budget constraints comparable to those supported by private agents. As a consequence, the potential for capture, rent-seeking, and resource dissipation is intrinsic to all states. Such phenomena are not second-order institutional failures; rather, they are an integral part of the constitutional bargain between rulers and the governed. This is one reason why states around the world differ as much in their present structure as in their capacity to address and redress this pattern.

\subsection{Institutionalization, cumulativity, and irrevocability ${ }^{14}$}

Under any constitution, individuals (collectively organized or not) bargain with the rulers to try to consolidate and extend their rights. In turn, rulers derive wealth and other social benefits from the recognition of their legitimacy. Fig. 1 summarizes our understanding of the "engine" of this evolution. Enfranchisement, in both the economic and political sphere, empowers the governed and provides them with additional capacities to innovate and to bargain with rulers. Thus might begin a virtuous loop resulting in economic growth and a reinforcement of the public order's legitimacy, but only if the rule of law develops so as to frame public action both in the economy and in the polity. This becomes possible with the development of a neutral and efficient bureaucracy that effectively administers both economic and civic rights.

However, the ultimate outcome of a given constitutional bargain is in what agents actually do with their rights, in their every day life - that is, how civil society and the economy actually work and develop over time. Because rights formalize the main rules of the game in society, they bear in a most powerful way on how agents invest, pool resources, trade, innovate and possibly try to dislodge less efficient producers. As they enfranchise and empower agents, new rights open roads to ingenuity and entrepreneurship (think to joint-stock companies or intellectual property titles). Capital, know-how, cooperative networks, individual balance sheets are then built up on the assumption that those rights will hold. Yet, this built-up is ultimately the reason why rights often hold: as they enfranchise agents, they shape investments, allow more production. Rights then become components of the social machine. They structure and frame the new exchanges that have become possible. This is especially true for constitutional commitments. Rather than wondering endlessly why governments ever remain faithful to their promises, or why changing coalition between elite fractions may ever endorse them, one should first look at what individual agents do with their rights. And the response is: they may well try to increase their revenue.

Since Adam Smith, we know that societies hold together because of the huge mutual interest all agents have in preserving the division of labor, hence the wealth and security they derive from it. As he made clear in his definition of what political economy is about, this requires that the production of both private and public goods are well understood and cared for. The intuition we tried to formalize in this model is that this is indeed what citizens are about as they bargain with their rulers on individual rights and public bureaucracies. And legal norms persist over time because they are embodied in the dense web of mutual interdependences behind any investment on any form of capital; either physical, human or intangible.

\footnotetext{
${ }^{14}$ A process is irrevocable if it is no longer possible to go back from a given state to any previous one. In contrast, with an irreversible process it is possible to return to a previous state-but just not by the reverse path.
} 


\section{Conclusion}

In contrast to alternative and complementary analyses of the relationship between macro institutions and development, our framework underscores that modern societies and their states, while implementing and guaranteeing the "social" contract, cannot rightly be understood as simple equilibria of dominant strategies among coalitions. Both legal ordering and procedural organizations, once settled, become autonomous to individuals and even society. Furthermore, this autonomy depends precisely on the joint development of and interplay between the rule of law and the Weberian bureaucracy. This dynamic leads in particular to the increased formalization (guaranteeing impersonality) and hierarchization (guaranteeing equality and efficiency) of norms and organizations both. The strength of this legal-bureaucratic combination is that it is adhered to by individuals, who understand that guaranteed rights-even when unequal or imperfect-enable them to build and manage their personal interest (i.e., better so than in a context of violence and civil war). Also, rights are embodied by economic mutual commitments (contracts, balance sheets, etc.) and assets, that is the current accumulation and distribution of wealth and production capacities, which contribute to their credibility and irreversibility.

From this perspective, the potential of a liberal consititutionalization is that it is intrinsically dynamic while still providing safety. It relies on a credible commitment among members of the society that allows each to pursue his own individual interest while taking into account the interest of others. This is one consequence of the principle of equality in rights. Security then favors negotiability. Established rights (which include procedures) constitute limits on what can be negotiated, and equality in rights favors a negotiation process "behind the veil of ignorance". Here all individuals realize that the rights granted to some might actually benefit all, which facilitates agreements. In turn, negotiability fosters adhesion to the order: unsatisfied agents need not opt out, because they have the option to negotiate. The process of liberal constitutionalization therefore entails a permanent possibility of renewal. Negotiability allows experimentation and innovation. The combination of security and negotiability of rights also explains why a liberal order fosters growth. The facilitated trade and innovation stimulate division of labor and development of knowledge.

All in all, our approach of formalization and hierarchization of both the legal system and the public bureaucracy distinguishes this work from the public choice approach (from which we nonetheless borrow many elements) to relations between the law, the polity, and the economy. Our approach emphasizes that the space in which interests are negotiated must be built; there is no "natural" battlefield. This space relies on an individually nonnegotiable discipline even when it is collectively negotiated. Its rules of the game allow for agreeing on respective rights but also for building the collective interest. In the end, the law and the public bureaucracy promote the existence of a collective intentionality built on the seeking of individuals for enfranchisement and security, thus leading to economic growth and innovation. However, neither a state without law (as illustrated by Russia) nor a legal order without a state (as exemplified by "the Washington consensus") can guarantee development of the growth-and-legitimacy loop identified in this paper.

In our approach, the constitution is an institutional combination comprising a set of nonnegotiable meta-rules that may evolve under the influence of myriad cumulative negotiations among agents. The process of constitutionalization is thus open-ended and may result in highly contrasting socio-politic arrangements, given alternative paths of cumulative effects. Diversity in paths and in paces of evolutions is an important issue, because recognition of mutual rights and agreement on the governance of public goods provision may lead to discrepancies between and/or infringement across national communities. The challenge for this framework remains to accommodate convergence and integration of the various national experiences of constitutionalization in the context of international relations; therefore, we do not propose any ended vision of history.

Although the model we have presented here is obviously abstract and generic, we consider it to be primarily geared for empirical, comparative analysis of development trajectories. This is ultimately the reason for our insistence on constitutionalized rights. Rights are not only different across more or less despotic or liberal societies. Because they are bargained over, and then invested in social action and entrepreneurship, they bear decisively on the long term dynamics of development, hence on the future political bargain. They are the link between the political process and the economy, though without being founded neither in some self-referential commitments, nor in transitory coalition of interests.

\section{References}

Acemoglu, D., Ticchi, D., Vindigni, A., 2007. Emergence and Persistence of Inefficient States. MIT, Urbino and Princeton Universities, mimeo. 59 p. Aoki, M., 2001. Towards a Comparative Institutional Analysis. MIT Press, Cambridge, Ma.

Arruñada, Benito, forthcoming. Foundations of Impersonal Exchange: The Theory and Policy of Contractual Registries. University of Chicago Press, Chicago. Barro, R., 1991. Determinants of Economic Growth: A Cross-Country Empirical Study. The MIT Press, Cambridge, MA.

Barzel, Y., 1989. Economic Analysis of Property Rights. Cambridge UP, Boston.

Bernstein, L., 1992. Opting out of the legal system: extralegal contractual relations in the diamond industry. Journal of Legal Studies $21,115-157$.

Bernstein, L., 2001. Private commercial law in the cotton industry: creating cooperation through norms, rules, and institutions. Michigan Law Review 99, 1724-1788.

Brooks, C.W., 1986. Pettyfogers and Vipers of the Commonwealth, the 'Lower Branch' of the Legal Profession in Early Modern England. Cambridge. Brooks, C.W., 2008. Law, Politics and Society in Early Modern England. Cambridge University Press, Cambridge. 456 p.

Brousseau, E., Raynaud, E., forthcoming. Climbing the hierarchical ladders of rules: a life-cycle theory of institutional evolution. Journal of Economic Behavior and Organization.

Cromartie, A., 2006. The Constitutionalist Revolution. An Essay on the History of England, 1450-1642. Cambridge University Press, Cambridge. 309 p.

Dixit, A., 2004. Lawlessness and Economic Governance. Princeton University Press.

Evans, P., 1995. Embedded Autonomy: States and Industrial Transformation. Princeton University Press, Princeton. 
Evans, P., Rauch, J.E., 1999. Bureaucracy and Growth: A Cross-National Analysis of the Effects of 'Weberian' State Structures on Economic Growth. American Sociological Review 64, 748-765.

Greif, A., 1993. Contract enforceability and economic institutions in early trade: The Maghribi traders' coalition. American Economic Review 83 (3), $525-$ 548.

Greif, A., 2005. Commitment, coercion and markets: the nature and dynamics of institutions supporting exchange. In: Ménard, C., Shirley, M. (Eds.), Handbook of New Institutional Economics. Kluwer Academic Press, pp. 727-786.

Greif, A., 2006. Institutions and the Path to the Modern Economy: Lessons from Medieval Trade. Cambridge University Press.

Greif, A., 2008. Toward Political Economy of Implementation: The Impact of Administrative Power on Institutional and Economic Developments. In: Helpman, E. (Ed.), Institutions and Growth. Harvard University Press, pp. 17-63.

Gwartney, J.D., Holcombe, R.G., Lawson, R.A., 2006. Institutions and the impact of investment on growth. Kyklos 59 (2), 255-273.

Hadfield, G.K., 2008. The levers of legal design: institutional determinants of the quality of law. Journal of Comparative Economics 36, 43-73.

La Porta, R., Lopez-de-Silanes, F., Shleifer, A., Vishn, R.W., 1998. Law and finance. Journal of Political Economy 106 (6), 1113-1155.

La Porta, R., Lopez-de-Silanes, F., Shleifer, A., 2008. The economic consequences of legal origin. Journal of Economic Literature 46 (2), 285-332.

Merton, R.K., 1940. Bureaucratic structure and personality. Social Forces 17, 560-568.

Milgrom, P.R., North, D.C., Weingast, B.R., 1990. The role of institutions in the revival of trade: the law merchant, private judges, and the champagne fair. Economics and Politics $2(1), 1-23$.

Muldrew, C., 1998. The Economy of Obligation: the Culture of Credit and Social Relations in Early Modern England. Palgrave Macmillan, London.

Murrell, P., 2009. Design and Evolution in Institutional Development: the Insignificance of the English Bill of Rights. Working Paper, U. Maryland. <http:// ssrn.com/abstract $=1522864>$.

Nee, V., 2000. The role of the state in making a market economy. Journal of Institutional and Theoretical Economics 156, 64-88.

North, D.C., 1981. Structure and Change in Economic History. Cambridge University Press, Cambridge.

North, D.C., 1990. Institutions, Institutional Change, and Economic Performance. Cambridge University Press, New York.

North, D., Weingast, B., 1989. Constitutions and commitment: evolution of institutions governing public choice. Journal of Economic History 44, 803-832.

North, D.C., Wallis, J.J., Weingast, B.R., 2009. Violence and Social Orders: A Conceptual Framework for Interpreting Recorded Human History. Cambridge University Press, Cambridge.

Olson, M., 1993. Dictatorship, democracy, and development. The American Political Science Review 87 (3), 567-576.

Olson Jr., M., 2000. Power and Prosperity: Outgrowing Communist and Capitalist Dictatorships. Basic Books, New York.

Ostrom, E., 1990. Governing the Commons, the Evolution of Institutions for Collective Action. Cambridge University Press, Cambridge.

Pincus, S., 2009. 1688, The First Modern Revolution. Yale University Press, Yale. 647 p.

Pirrong, S.C., 1995. The efficient scope of private transaction-costs-reducing institutions: the successes and failures of commodity exchanges. Journal of Legal Studies XXIV, 229-255.

Pocock, J.G.A., 1987. The Ancient Constitution and the Feudal Law, A Study of English Historical Though in the Seventeenth Century. Cambridge University Press, Cambridge.

Posner, R.A., 1972. Economic Analysis of Law. Little Brown Cy, Boston.

Rajan, R.G., Zingales, L., 2003. The great reversals: the politics of financial development in the twentieth century. Journal of Financial Economics 69, 5-50. Richman, B.D., 2004. Firms, courts, and reputation mechanisms: toward a positive theory of private ordering. Columbia Law Review 104 (8), $2328-2368$. Tabellini, G., 2005. The Role of the State in Economic Development. Kyklos 58 (2), 283-303.

Tirole, J., 1994. The Internal Organization of Government. Oxford Economic Papers 46, 1-29.

Weber, M., [1922] 1978. Economy and Society. University of California Press, Berkeley.

Weber, M., [1918] 1988. Parlament und Regierung im neugeordneten Deutschland. In: Weber, M. (Ed.) Gesammelte Politische Schriften, fifth ed., Tübingen, pp. 306-443.

Williamson, O.E., 1996. The Mechanisms of Governance. Oxford UP, Oxford.

Wilson, J.Q., 1989. Bureaucracy: What Government Agencies Do and Why They Do It. Basic Books, New York. 